\title{
Corrigendum
}

\section{Genetic variation in milk urea nitrogen concentration of dairy cattle and its implications for reducing urinary nitrogen excretion - CORRIGENDUM}

\author{
P. R. Beatson, S. Meier, N. G. Cullen and H. Eding \\ doi: 10.1017/S1751731119000235, published by Cambridge University Press 27 February 2019
}

The original article contained two incorrect citations. The correct citations with references are shown here.

The Introduction, right hand column on the second page should read as follows;

In a meta-analysis of eight publications, Aizimu et al. (2013) reported a significant asymptotic (negative) relationship between nitrogen use efficiency and MUN in groups of NZ Jersey (J) and Holstein-Friesian (HF) cows.

The Results and discussion, left hand column on the fifth page should read as follows;

However, Aizimu et al. (2013) reported a negative asymptotic relationship between MUN and protein-use efficiency in a metaanalysis.

The authors apologise for the error.

\section{References}

Aizimu W, Hodge S, Edwards GR, Dewhurst RJ, and Cheng L 2013. Brief communication: can milk urea nitrogen differentiate nitrogen use efficiency of lactating cow groups raised on New Zealand pasture? Proceedings of the New Zealand Society of Animal Production 73, 199-201.

Beatson PR, Meier S, Cullen NG and Eding H 2019. Genetic variation in milk urea nitrogen concentration of dairy cattle and its implications for reducing urinary nitrogen excretion. Animal, first published online 27 February 2019, doi: 10.1017/S1751731119000235 